\title{
Linking Autism and Alzheimer's: An integrated approach
}

\author{
Nadira Pardo* and Andrew Thomson \\ California Southern University, USA
}

Submission: January 31, 2017; Published: March 03, 2017

*Corresponding author: Nadira Pardo, California Southern University, 3330 Harbor Blvd, Costa Mesa, CA 92626, USA,

Email: Nadira.Pardo@my.calsouthern.edu

Keywords: Autism spectrum disorder (ASD)

\section{Introduction}

With the new clinical trials of medication for treatment of Alzheimer's beginning in Australia based upon the research of Austin Hospital Associate Professor Michael Woodward in Melbourne SBS [1], the first thing to consider is its implications for Autism Spectrum Disorder. Previous treatments for Alzheimer's attempted to eliminate the amyloid protein buildup but the new CT1812 being tested examines how proteins bind to the receptors involved in cell communication. Memory in mice has been shown to improve in pre-clinical trials, according to Prof. Woodward SBS [1], so everyone is optimistic about its implications for human memory in the elderly. But how can this process are prevented?

Going back to the beginning, with Vitamin D levels of pregnant women being shown to cause neuronal developmental issues later on in their children Scott [2], and the link between lower Vitamin D levels and their own neuronal health Richards [3], linking this to telomere length and health risks later in life may include cancer, schizophrenia, and autism. Professor John McGrath of the Queensland Brain Institute says that the research conducted shows that low Vitamin D levels "disrupt brain development" Scott [2] which includes Autism Spectrum Disorder (ASD). However, biological predisposition is only the beginning.

Psychological stress has been shown to increase the rate of telomere shortening Mather [4], and also reduce vitamin D uptake in the body Harvard Medical School [5]. So how can we, as educators and health care professionals take an integrated approach to stress reduction that may facilitate the reduction of telomere breakage and thus slow or prevent the onset of Alzheimer's or reduce the impact of ASD? Taking a phased approach to social psychological development, linking to physical development, as an integrated health and wellness approach, we suggest would include a return to Piaget's 1936 theory of cognitive development McLeod [6]. When working with either end of the spectrum, whether working with childhood autism or the aged with Alzheimer's, if an assessment can be conducted to determine which phase of development the client is in, this may be able to reduce the level of perceived stress when performing daily tasks or routines, or especially when introducing new concepts such as shifting into an aged care facility, or learning the alphabet in school.

Thus, putting aside the traditional aged norms in Piaget's theory McLeod [6], which may or may not apply due to telomere reduction or disruption of protein synthesis, it would be important for staff such as teachers, school psychologists, teacher's aides or aged care helpers to become aware of the needs associated with the stage of development the client is in based upon their own personal biological and psychological development, older or younger [7-11].

\section{Conclusion}

By adjusting and amending the chronological aged norms in Piaget's theory linked to the specific stages of development, and being able to adjust for direction of that development, with both autistic and Alzheimer's patients reversing in mental age more often than not, we can view the assessment as a matching process. By matching the Piaget's stage to each client, we can adjust tasks and procedures to reduce the overall stress the client may be subjected to, and thus prevent further advancement of these illnesses.

\section{References}

1. SBS (2016) "Australian Trials for New-approach Alzheimer's drug”.

2. Scott S (2016) Autism linked to lack of vitamin D during pregnancy, study finds. 
3. Richards JB, Valdes AM, Gardner JP, Paximadas D, Kimura M, et al (2007) higher serum vitamin D concentrations are associated with longer leukocyte telomere length in women. Am J Clin Nutr 86(5): 1420-1425.

4. Mather MB et al (2016) Perceived stress and telomere length: A systematic review, meta-analysis, and methodologic considerations for advancing the field. Brain behav Immun 54: 158-169.

5. Harvard Medical School (2011) 9 things that can undermine your vitamin D level. Harvard health publications, USA.

6. McLeod S (2015) Jean Piaget.

7. Kota LN, Purushottam M, Moily NS, Jain S (2015) Shortened telomere in unremitted schizophrenia. Psychiatric Clinical Neuroscience 69(5): 292-297.
8. Li Z, Tang J, Li H, Chen S, He Y, et al. (2014) shorter telomere length in peripheral blood leukocytes is associated with childhood autism. Science Report 4: 7073.

9. Main PA, Thomas P, Angley MT, Young R, Esterman A, et al. (2014) Lack of evidence for genomic instability in Autistic children as measured by the cytokinesis-block micronucleus cytome assay. Autism Research (1): 94-104.

10. Mitchell C, John H, McLanahan S, Susan RS, Arthur B, et al. (2014) Social disadvantage, genetic sensitivity, and children's telomere length. PNAS of USA 111(16): 5944-5949.

11. Muezzinler A, Zaineddin AK, Brenner H (2013) A systematic review of leukocyte telomere length and age in adults. Aging Research Reviews 12(2): 509-519.

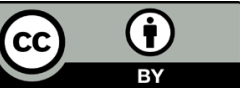

This work is licensed under Creative Commons Attribution 4.0 Licens DOI: 10.19080/JOJCS.2017.02.555583
Your next submission with Juniper Publishers will reach you the below assets

- Quality Editorial service

- Swift Peer Review

- Reprints availability

- E-prints Service

- Manuscript Podcast for convenient understanding

- Global attainment for your research

- Manuscript accessibility in different formats

( Pdf, E-pub, Full Text, Audio)

- Unceasing customer service

Track the below URL for one-step submission https://juniperpublishers.com/online-submission.php 